\title{
NATIVE PLANTS DOMINATE UNDERSTORY VEGETATION FOLLOWING PONDEROSA PINE FOREST RESTORATION TREATMENTS
}

\author{
Michael T. Stoddard1,3, Christopher M. McGlone1,2, Peter Z. Fulé1,2, \\ Daniel C. Laughlin ${ }^{1}$, and Mark L. Daniels ${ }^{1}$
}

\begin{abstract}
Dense ponderosa pine forests in the southwestern United States inhibit understory production and diversity and are susceptible to high-severity wildfire. Restoration treatments involving overstory thinning and prescribed burning are being implemented to increase understory productivity and diversity and to reduce the risk of severe wildfire. However, disturbances associated with treatments may favor invasion of nonnative species, and the severity of the disturbance may be related to the level of nonnative species establishment. We examined understory community composition, species richness, and plant cover responses to 3 stand-scale replicates of 4 different tree-thinning intensities. Restoration treatments altered the composition of the understory community regardless of thinning intensity. Understory richness and cover were highly variable among experimental blocks, but we observed strong trends of increasing richness and cover in the treated stands. Immediately following restoration treatments, nonnative species cover comprised $6 \%$ of the total cover where treatment-induced disturbances were the greatest. However, the initial increase in nonnative species did not persist and was reduced by half 6 years after treatment. Plant community composition was still in flux by the sixth year after treatment, indicating that continued monitoring is necessary for evaluating whether restoration targets are maintained over time.
\end{abstract}

RESUMEn.-Los densos bosques de pino ponderosa en el suroeste de los E.U.A. inhiben la producción y diversidad del sotobosque y son propensos a incendios severos. El raleo del dosel y la quema controlada se están implementando como tratamientos de restauración para incrementar la productividad y diversidad del sotobosque y para reducir el peligro de incendios severos. Sin embargo, las perturbaciones asociadas con estos tratamientos podrían favorecer la invasión por especies no nativas, y la severidad de la perturbación puede estar relacionada con el nivel de establecimiento de estas especies. Examinamos la reacción del sotobosque con respecto a la composición de sus comunidades, a la riqueza de especies y a la cobertura de la vegetación, a tres réplicas a nivel de rodal de cuatro distintas intensidades de raleo. Los tratamientos de restauración cambiaron la composición de la comunidad del sotobosque independientemente de la intensidad del raleo. La riqueza y la cobertura del sotobosque variaron mucho entre las áreas estudiadas, pero observamos marcadas tendencias de mayor riqueza y cobertura en los rodales que recibieron el tratamiento. Inmediatamente después de los tratamientos de restauración, la cobertura de especies invasoras constituía el 6\% de la cobertura total donde las perturbaciones producidas por los tratamientos fueron más grandes. No obstante, el aumento inicial en la cobertura de especies invasoras no persistió, y se redujo a la mitad en un lapso de seis años después del tratamiento. La composición de las comunidades de plantas aun seguía cambiando en el sexto año después del tratamiento, lo cual indica que será preciso el monitoreo continuo para determinar si se lograron las metas de restauración.

Ponderosa pine (Pinus ponderosa) forests of the southwestern United States have higher stand densities and basal areas at present than they had prior to Euro-American settlement (pre-1876; hereafter referred to as "presettlement”) (Allen et al. 2002, Moore et al. 2004). The altered forest structure has led to many critical conservation problems, including loss of native plant diversity and productivity (Bakker and Moore 2007, Laughlin et al. 2011) and increased severity of wildfire (Covington and Moore 1994). Tree thinning and prescribed fire are common practices for reducing the severity of wildfires in forests adapted to low-severity, frequent-fire regimes. Currently, there is increased interest in adopting thinning-and-burning methods that incorporate ecological restoration principles (as defined by SER 2004) to promote overall forest health while still meeting fuels reduction objectives (Covington et al. 1997, Roccaforte et al. 2010). However, the effectiveness of such ecological restoration treatments in native understory recovery has not been conclusively demonstrated.

Historical reconstruction of forest structure through the use of site-specific evidence from a predetermined time period (e.g., pre-EuroAmerican settlement) is one technique for

${ }^{1}$ Northern Arizona University, Ecological Restoration Institute, Box 15017, Flagstaff, AZ 86011.

${ }^{2}$ Northern Arizona University, School of Forestry, Box 15018, Flagstaff, AZ 86011

${ }^{3}$ E-mail: mike.stoddard@nau.edu 
developing restoration prescriptions (Hobbs and Norton 1996, Moore et al. 1999). Trees are thinned to replicate historical forest structure and are burned to remove excessive fuels, promote understory productivity, and stimulate soil nutrient cycling (hereafter thinning-andburning treatments are referred to as "restoration treatments"). Tree density is determined by extant historical evidence (old growth trees, snags, stumps) with an additional number of younger trees retained to replace historical trees that may not have left evidence and trees that might be lost during and after treatment implementation. In northern Arizona, several studies have used stocking rates of 150\%-300\% of historical evidence in order to reduce fuel loads and the potential for crown fire, as well as to increase herbaceous diversity and production (Fulé et al. 2005, Laughlin et al. 2006, Moore et al. 2006, McGlone et al. 2009b). There are, however, ecological reasons for maintaining higher numbers of trees in some areas (e.g., to provide wildlife habitat), as well as political and social constraints associated with thinning in protected lands such as national parks. Furthermore, achieving 150\%-300\% stocking rates can require intensive tree removal, which can be expensive, logistically challenging (Fulé et al. 1997, Mast et al. 1999), and damaging to the soil profile (Korb et al. 2007). Reduced levels of tree thinning may accomplish the desired ecological goals, such as reduced crown fire risk, while preserving habitat for dense-forest-dwelling species, facilitating implementation on protected lands, and reducing the cost of implementation. Whether retaining more trees will achieve the goal of increasing native understory production and diversity is unclear. The structure and composition of understory communities following restoration treatments in ponderosa pine forest are often influenced by thinning intensity (Abella and Covington 2004) and the level of disturbance generated during treatment implementation (Wienk et al. 2004, McGlone et al. 2009b). Restoration treatments can also have the unintended consequence of promoting invasion and potential community dominance of nonnative species (McGlone et al. 2009a).

To better understand the relationship of treethinning intensity to understory abundance and richness, we established a fully-replicated, stand-scale thinning-and-burning experiment that included 4 levels of tree thinning followed by prescribed fire. We hypothesized that (1) there would be a strong positive relationship between tree-thinning intensity and understory plant richness and abundance, and (2) there would be a strong positive relationship between increased tree thinning and nonnative species abundance.

\section{Methods}

\section{Study Area}

This research was conducted within and adjacent to the Fort Valley Experimental Forest, a 2003-ha mixed-age ponderosa pine reserve located approximately $15 \mathrm{~km}$ northwest of Flagstaff, Arizona, in the Coconino National Forest $\left(35^{\circ} 16^{\prime} 19^{\prime \prime} \mathrm{N}, 111^{\circ} 41^{\prime} 22^{\prime \prime} \mathrm{W}\right)$. Elevation of the study area is $2250 \mathrm{~m}$ with slope gradients $<25 \%$. Soils are a basalt-derived complex of fine, smectitic, frigid Typic Argiborolls and Mollic Eutroboralfs (Miller et al. 1995). The average annual temperature is $7.5^{\circ} \mathrm{C}$. Long-term (50-year) average annual precipitation is $57 \mathrm{~cm}$ (Moore et al. 2006). Precipitation patterns for the region are typically bimodal, with approximately half of the precipitation occurring as rain in July and August and half as snow in the winter (NOAA 2005). Drought conditions prevailed during the study period (particularly in 2002), with mean annual precipitation at $43.3 \mathrm{~cm}$.

Vegetation at the study site is dominated by Pinus ponderosa, consisting of groups of mature, presettlement trees intermixed with numerous dense thickets of smaller-diameter trees. Pretreatment tree density in 1998 was approximately 1156 trees $\cdot \mathrm{ha}^{-1}$, compared to an estimated density of 140 trees $\cdot$ ha $^{-1}$ prior to European settlement, circa 1876 (Korb et al. 2007).

\section{Experimental Design and Restoration Treatments}

In 1998, we established 3 experimental blocks, each containing 4 thinning-intensity treatment units of approximately 14 ha. Each unit within the blocks was randomly assigned a treatment. Tree-thinning intensity was based on historical reconstruction of site-specific overstory density and spatial arrangement. Thinning treatment protocol retained all living presettlement trees (Covington and Moore 1994, Fulé et al. 2001). In addition, differing 
numbers of post-1876 trees were retained as replacements for remnant evidence of missing presettlement trees (e.g., snags, logs, stumps). Replacement trees were retained at the following levels: (a) 1.5-3 trees per remnant presettlement evidence (high-intensity thinning), (b) 2-4 trees per remnant presettlement evidence (medium-intensity thinning), (c) 3-6 trees per remnant presettlement evidence (low-intensity thinning), and (d) no thinning (control). All thinned units were also treated with broadcastprescribed fire. Treatment units were thinned in 1999 and burned in spring 2000 (block 3) and spring 2001 (blocks 1 and 2). Following treatment, tree density was significantly different among thinning treatments, with the high-intensity thinning treatments having the lowest densities (Korb et al. 2007). Soil disturbances were highly variable among each block as a result of different harvesting methods, with block 3 having the highest soil disturbance (Korb et al. 2007).

\section{Field Methods}

Prior to treatment, we established 20 permanent monitoring plots in each of the 12 treatment units $(20$ plots $\times 3$ blocks $\times 4$ treatment units $=240$ total plots). Individual plots were placed systematically on a $60-\mathrm{m}$ grid, with a random starting point for the grid. Sampling protocol for herbaceous vegetation was modified from the National Park Service firemonitoring protocol (USDI NPS 2003). Each plot contained one 50-m point-line intercept transect oriented parallel to the prevailing slope and centered on plot center. Herbaceous plants were recorded at points located every $30 \mathrm{~cm}$ along each transect for a total of 166 points per plot. We estimated plant foliar cover (\%) by dividing the number of plant occurrences along the transect by 166 points. In addition, a complete species list of all herbaceous plants was recorded within a $10 \times 50-\mathrm{m}$ $\left(500-\mathrm{m}^{2}\right)$ belt transect using the point-line intercept transect as the midline. We sampled vegetation during July and August of 1998, 2001, 2002, and 2006. Taxonomic nomenclature and species nativity were based on the USDA Plants Database (USDA NRCS 2009). Taxa that could not be reliably identified to species in the field were only identified to genus. Tree canopy cover was measured using a vertical densitometer every $3 \mathrm{~m}$ along the point-line intercept transect. All other tree measurements were taken within a $400-\mathrm{m}^{2}$ (11.28-m radius) circular fixed-area plot.

\section{Statistical Analyses}

We used nonmetric multidimensional scaling (NMS) to examine changes in understory community composition over time and among experimental treatments (Clarke 1993). Community composition matrices were summarized for each treatment unit $(n=3)$ in each sampling year. A frequency value was calculated for each species by summing its presence across belt transects within a treatment unit and then dividing by 20 , the total number of transects within the unit. We omitted species that occurred on $<5 \%$ of the treatment units from the ordination and from analyses of species composition (McCune and Grace 2002). We ran the ordination using the BrayCurtis distance measure, random starting configurations, 100 runs with real data, a maximum of 100 iterations per run, and a stability criterion of 0.00001 . The final solution was compared to random solutions by using a Monte Carlo test with 9999 randomizations. All ordinations were conducted using PC-ORD software (version 5.10; McCune and Mefford 2006).

We tested for differences in pretreatment (1998) and final (2006) community composition among treatments using permutational MANOVA (PerMANOVA; Anderson 2001), with Bray-Curtis dissimilarity as our distance measure (Faith et al. 1987) and 9999 permutations. PerMANOVA was conducted using PCORD software (version 5.10; McCune and Mefford 2006). The test for a time $\times$ treatment interaction was assessed by calculating the multivariate dissimilarity (Bray-Curtis distance) from 1998 to 2006 for each treatment unit. This calculation produced a univariate response variable that we analyzed with a Kruskal-Wallis test and post hoc Wilcoxon's 2-sample tests for pairwise comparisons (JMP software, version 8.0; SAS Institute, Inc. 2004). A significant result from these tests would indicate that the treatment with greater dissimilarity experienced a greater change in community composition between 1999 and 2006.

Indicator species analysis (ISA) was used to explain the results of the PerMANOVA by identifying which species were most abundant and most frequent within treatments in a particular year (Dufrêne and Legendre 1997). An 


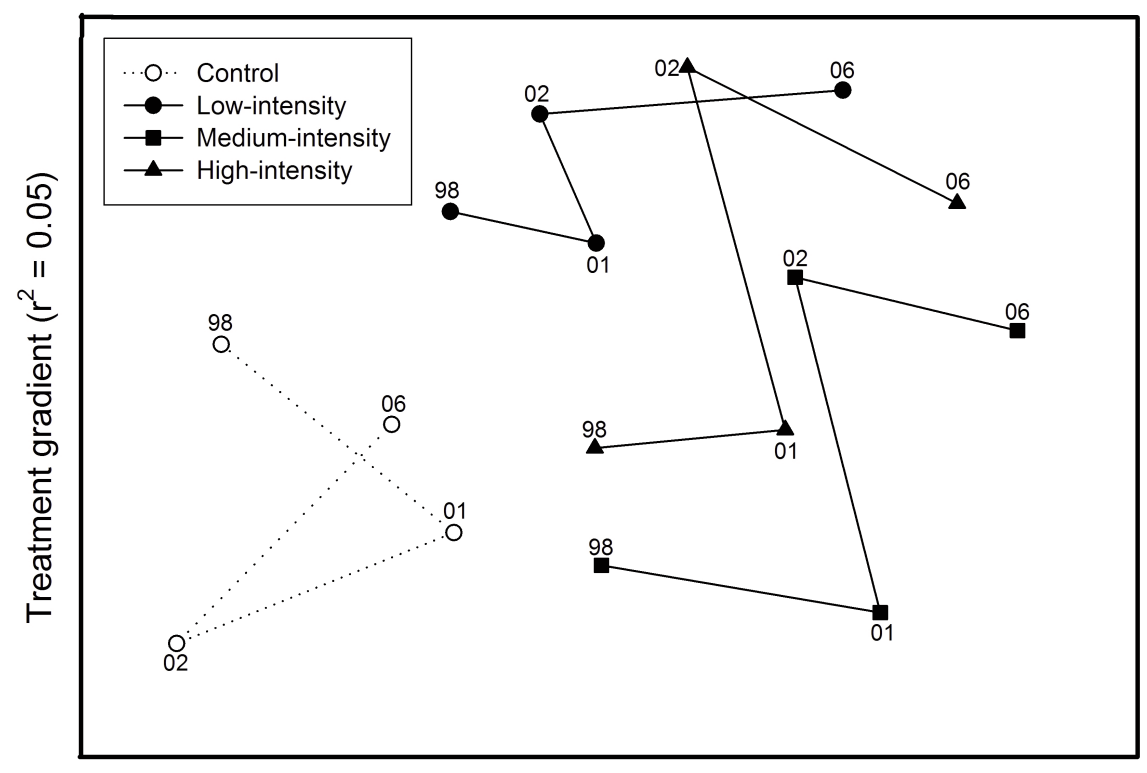

Temporal gradient $\left(r^{2}=0.88\right)$

Fig. 1. Nonmetric multidimensional scaling (NMS) ordination of the understory plant community. Each symbol represents a treatment unit in one year. Lines connect treatment units from 1998 (pretreatment) to 2001, 2002, and 2006. The final solution had 2 dimensions and represented 93\% of the variation of the Bray-Curtis distance matrix (stress 9.1, $P=0.0001$ ).

indicator value (INDVAL) is the product of the relative abundance and relative frequency (calculated by species presence on number of belt transects). Species were considered significant indicators of the treatment if the indicator value (INDVAL) was $>25$ and if the $P$-value was $<0.05$ (calculated using Monte Carlo randomizations). An INDVAL of 25 would occur, for example, if a species occurred on $50 \%$ of the belts in a group and had a relative abundance of at least $50 \%$ in that group. ISA was conducted using PC-ORD software (version 5.10; McCune and Mefford 2006).

We analyzed posttreatment differences of understory richness and cover among treatments in 2006 with analysis of covariance (ANCOVA). Pretreatment condition was used as a covariate, and the ANCOVA was followed by Tukey's honestly significant difference (HSD) post hoc multiple comparisons test. All richness and cover data met the assumptions of normality and homogeneity of variance based on the Shapiro-Wilk test and Levene's test, respectively. Differences in thinning levels were assessed at $\alpha=0.1$. These tests were conducted using JMP software (Version 8.0; SAS Institute, Inc. 2004). We used linear regression to analyze the relationships among tree characteristics and understory responses. To facilitate examination of localized variability in treatment responses, we also present understory richness and cover for each block.

\section{RESUlts}

We detected 203 vascular plant species across treatment units in 1998-2006, with 168 species remaining after application of the $5 \%$ filter. Plant community composition was similar among treatments in 1998 prior to treatment (PerMANOVA: $P=0.62$ ). After treatment, plant community composition in the 3 thinning treatments diverged marginally from the control $(P=0.10)$, but no differences were detected between thinned units. The net change in composition from 1998 to 2006 was marginally greater among treated units compared to control units $(P=0.10)$. The NMS ordinations showed little compositional change in the control units over time and a greater change in the treated units, though all 3 treatments had similar magnitudes of change over time (Fig. 1).

No species had strong indicator values (INDVAL > 50) in any year or treatment 
TABLE 1. Indicator species associated with sampling year and treatment unit. All species listed had an indicator value $>25$ and $P<0.05$. $\mathrm{AB}=$ annual/biennial forb; $\mathrm{P}=$ perennial forb; $\mathrm{G}=$ perennial graminoid; $\mathrm{T}=$ tree; $\mathrm{NN}=$ nonnative species.

\begin{tabular}{|c|c|c|c|c|}
\hline Year & Indicator species & Treatment & Life form & $\%$ plots $^{b}$ \\
\hline 1998 & No indicator species & All treatments & - & - \\
\hline \multirow[t]{13}{*}{2001} & Elymus elymoides & Control & G & 100 \\
\hline & Pinus ponderosa & Control & $\mathrm{T}$ & 67 \\
\hline & Solidago spp. & Low-intensity & $\mathrm{P}$ & 87 \\
\hline & Chenopodium spp. & Medium-intensity & $\mathrm{AB}-\mathrm{NN}$ & 69 \\
\hline & Lactuca serriola & Medium-intensity & $\mathrm{AB}-\mathrm{NN}$ & 27 \\
\hline & Linaria dalmatica & Medium-intensity & $\mathrm{P}-\mathrm{NN}$ & 43 \\
\hline & Polygonum douglasii & Medium-intensity & $\mathrm{AB}$ & 68 \\
\hline & Astragalus humistratus & High-intensity & $\mathrm{P}$ & 83 \\
\hline & Ceanothus fendleri & High-intensity & $\mathrm{P}$ & 90 \\
\hline & Cirsium vulgare & High-intensity & $\mathrm{P}-\mathrm{NN}$ & 12 \\
\hline & Laennecia schiedeana & High-intensity & $\mathrm{AB}$ & 43 \\
\hline & Lotus spp. & High-intensity & $\mathrm{P}$ & 98 \\
\hline & Verbascum thapsus & High-intensity & $\mathrm{AB}-\mathrm{NN}$ & 75 \\
\hline \multirow[t]{13}{*}{2002} & No indicator species & Control & - & - \\
\hline & Solidago spp. & Low-intensity & $\mathrm{P}$ & 79 \\
\hline & Chenopodium graveolens & Medium-intensity & $\mathrm{AB}$ & 43 \\
\hline & Erigeron divergens & Medium-intensity & $\mathrm{P}$ & 42 \\
\hline & Laennecia schiedeana & Medium-intensity & $\mathrm{AB}-\mathrm{NN}$ & 75 \\
\hline & Linaria dalmatica & Medium-intensity & $\mathrm{P}-\mathrm{NN}$ & 42 \\
\hline & Taraxacum officinale & Medium-intensity & $\mathrm{P}-\mathrm{NN}$ & 25 \\
\hline & Verbascum thapsus & Medium-intensity & $\mathrm{AB}-\mathrm{NN}$ & 63 \\
\hline & Astragalus humistratus & High-intensity & $\mathrm{P}$ & 88 \\
\hline & Ceanothus fendleri & High-intensity & $\mathrm{P}$ & 92 \\
\hline & Cirsium vulgare. & High-intensity & $\mathrm{P}-\mathrm{NN}$ & 10 \\
\hline & Elymus elymoides & High-intensity & G & 100 \\
\hline & Lotus spp. & High-intensity & $\mathrm{P}$ & 85 \\
\hline \multirow[t]{9}{*}{2006} & No indicator species & Control & - & - \\
\hline & No indicator species & Low-intensity & - & - \\
\hline & Achillea millefolium & Medium-intensity & $\mathrm{P}$ & 61 \\
\hline & Linaria dalmatica & Medium-intensity & $\mathrm{P}-\mathrm{NN}$ & 61 \\
\hline & Potentilla crinita & Medium-intensity & $\mathrm{P}$ & 77 \\
\hline & Astragalus humistratus & High-intensity & $\mathrm{P}$ & 98 \\
\hline & Ceanothus fendleri & High-intensity & $\mathrm{P}$ & 95 \\
\hline & Cirsium wheeleri. & High-intensity & $\mathrm{P}$ & 98 \\
\hline & Lotus spp. & High-intensity & $\mathrm{P}$ & 67 \\
\hline
\end{tabular}

aRelative abundance $\times$ relative frequency (see Dufrene and Leg
bPercentage of belt transects in which the species was detected

(Table 1). Even before treatment, none of the units had significant indicator values, and the control and low intensity units never produced more than 2. After treatment, there was an increase in the number of species with significant indicator values in both the medium- and high-intensity treatments (Table 1). In the first 2 posttreatment years, the medium- and highintensity treatments had primarily nonnative species with significant indicator values. By 2006, only one nonnative species (Linaria dalmatica) had a significant indicator value in the medium-intensity treatment (Table 1). No nonnatives were significant indicator species in the control or low-intensity treatment in any year or prior to treatment in any treatment unit (Table 1).

Total species richness was significantly different among treatments $(P=0.043)$ in 1998 before treatment and after treatment in 2006 $(P=0.08)$, though no differences were detected among the multiple comparisons test (Table 2). The lack of detectable significant differences in the multiple comparisons test is likely an artifact of the low sample size and high variability in the data. There were strong trends in the data, with greater species richness in the treated units than in the control units 
TABLE 2. Mean (SE) of species richness and percent cover in 2006 across all blocks $(n=3)$ and within each individual block $(n=20)$. Different letters following means within rows indicate significant differences at $\alpha=05$.

\begin{tabular}{clcrr}
\hline & Control & Low intensity & Medium intensity & High intensity \\
\hline Species richness & & & & \\
Overall & $20.5(3.9) \mathrm{a}$ & $33.6(2.3) \mathrm{a}$ & $37.8(2.3) \mathrm{a}$ & $35.4(3.8) \mathrm{a}$ \\
$\quad$ Block 1 & $28.3(1.8)$ & $37.6(1.4)$ & $40.1(1.8)$ & $29.8(1.1)$ \\
Block 2 & $16.4(1.4)$ & $33.6(1.7)$ & $33.3(1.4)$ & $33.1(1.3)$ \\
Block 3 & $16.7(1.3)$ & $29.8(1.2)$ & $40.2(2.0)$ & $42.8(1.1)$ \\
Percent cover & & & & \\
Overall & $4.0(1.0) \mathrm{a}$ & $9.4(3.1) \mathrm{a}$ & $11.6(2.1) \mathrm{a}$ & $16.4(6.6) \mathrm{a}$ \\
Block 1 & $6.6(1.2)$ & $15.6(1.9)$ & $7.5(1.3)$ & $10.6(1.2)$ \\
Block 2 & $3.6(10.6)$ & $6.9(0.7)$ & $13.9(2.1)$ & $9.1(1.7)$ \\
Block 3 & $3.7(0.9)$ & $5.6(1.0)$ & & $29.6(3.1)$ \\
\hline
\end{tabular}

(Table 2). Examination of data from the individual blocks shows a varied response to treatment intensity, but, as with the overall analysis, species richness was always greater in the treated units than in the control units (Table 2). Species richness was positively related to both the percent change in canopy cover $\left(r^{2}\right.$ $=0.27, P<0.0001)$ and basal area $\left(r^{2}=0.38\right.$, $P<0.0001)$ as a result of tree removal. By the last 2 years of measurement, 2002 and 2006, nonnative species represented $<9 \%$ of the total species richness across all treated units, and by 2006 nonnative species richness was similar among all treatments $(P=0.25)$.

Total plant cover was not significantly different among treatments in 1998 before treatment $(P=0.42)$ or in 2006 after treatment $(P=0.34)$, even though total plant cover more than doubled in the low-intensity units and more than quadrupled in the high-intensity units as compared to the control units (Table 2). Native graminoid cover represented $95 \%$ of the total cover across all treatments. By 2006, graminoid cover had increased more than $470 \%$ in the high-intensity units and $53 \%$ in the control units compared to pretreatment measurements. Examination of data from the individual blocks shows a varied response to treatment intensity, but, as with the overall analysis, total cover was always greater in the treated units than in the control units (Table 2). Plant cover was positively correlated to both the percent change in canopy cover $\left(r^{2}=0.24, P<0.0001\right)$ and the tree basal area $\left(r^{2}=0.28, P<0.0001\right)$. By 2002 and 2006, the nonnative cover, as a proportion of total plant cover, represented $<6 \%$ of the total cover across all treated units, and was not significantly different among treatments $(P=0.20)$.

\section{Discussion}

Restoration treatments altered the composition of the ponderosa pine forest understory regardless of thinning intensity. However, the observed trend toward increasing species richness in the treated units was not significant. This result differs from other restoration treatments in ponderosa pine ecosystems where significant increases in species richness were observed (Metlen and Fiedler 2006, Moore et al. 2006, Laughlin and Fulé 2008). Nonnative species were an important component of the plant community immediately following the treatments. Within 2 years after treatment, 50\% and $45 \%$ of the indicator species in the medium- and high-intensity units, respectively, were nonnative species. However, this initial pulse of nonnative species was transient. Six years after treatment, nonnative species were only a minor component of the community. Only one nonnative species, Linaria dalmatica, remained as an indicator 6 years following restoration treatments, while the rest of the indicators were native perennials. Furthermore, L. dalmatica is the only nonnative species we detected that is listed as noxious by the state of Arizona (USDA NRCS 2009). By 2006, L. dalmatica had a mean foliar cover of $<2 \%$ across all treated units, although it was found on $67 \%$ of the treated plots.

There was a strong trend toward higher plant cover after restoration treatments, although plant cover on treatment units did not differ significantly from that on control units. Several studies have reported much larger changes within the first few years after restoration treatments than the changes we observed at Fort Valley (Laughlin et al. 2006, Moore et al. 2006). The lack of a statistically significant increase in native cover may be an artifact of the 
high levels of localized variability following restoration treatments. Given the known inverse relationship between herbaceous productivity and forest structure (Moore and Deiter 1992), we expected larger increases in understory cover across the entire study site in response to increased thinning intensity. Other studies have suggested that tree basal area needs to be reduced to $10 \mathrm{~m}^{2} \cdot \mathrm{ha}^{-1}$ or less before a significant increase in herbaceous production can occur (Uresk and Severson 1989, Sabo et al. 2009). Basal area at our site was reduced to 22.3 $\mathrm{m}^{2} \cdot \mathrm{ha}^{-1}$ in low-intensity units, $17.9 \mathrm{~m}^{2} \cdot \mathrm{ha}^{-1}$ in medium-intensity units, and $15.6 \mathrm{~m}^{2} \cdot \mathrm{ha}^{-1}$ in high-intensity units. It is reasonable to assume that we failed to reduce basal area to an appropriate threshold to induce the desired increase in understory plant cover.

Our results suggest that disturbances associated with restoration treatments can facilitate the establishment of nonnative species, although the increased presence of nonnatives does not necessarily result in a persistent invasion. Restoration treatments did promote an increase in nonnative species cover, but by 6 years posttreatment, the nonnative cover represented $<6 \%$ of the total cover across all treated units. Other studies have shown large increases in nonnative species cover in northern Arizona ponderosa pine forests following thinning-and-burning treatments (Griffis et al. 2001, Fulé et al. 2005, McGlone et al. 2009a). Generally, however, severe nonnative plant encroachment into postfire ponderosa pine forests, whether intentionally thinned and burned or burned in wildfires, occurs in areas near the lower ecotone with drier and warmer low-elevation ecosystems (Crawford et al. 2001, Laughlin and Fulé 2008, McGlone et al. 2009b). Burned ponderosa pine forests at higher elevations typically experience relatively low levels of nonnative plant encroachment (Huisinga et al. 2005, Kuenzi et al. 2008, Fornwalt 2010).

A notable exception, however, occurred at the Leroux Fire in northern Arizona, where high-severity burns resulted in a high abundance of Linaria dalmatica 2 years after the fire (Dodge et al. 2008). The high-severity areas on the Leroux Fire are potentially analogous to the slash pile burn scars at the Fort Valley restoration project. Two growing seasons after burning, the slash pile scars had significantly higher nonnative plant cover compared to burned areas away from the slash piles.
Furthermore, L. dalmatica was one of the dominant nonnatives associated with the postburn slash piles (Korb et al. 2004). While our study did not detect a persistent invasion by nonnatives, the risk of encroachment was, and may still be, a concern since we did find slightly higher occurrences of nonnative species across all treated areas.

\section{Conclusion}

The primary goals for the Fort Valley restoration project were to reduce tree densities to historical levels, increase native herbaceous production and diversity, and reduce fire hazards. Understory richness and cover was positively correlated with the reduction in tree basal area, and showed a trend toward increasing plant cover with increasing thinning intensities. Pine basal area may not have been reduced below the threshold necessary to generate a significant increase in understory cover.

All treatment units are presently dominated by native species 6 years after treatment. Initial posttreatment increases in nonnative species suggested that Fort Valley was at risk of invasion. By the sixth year after treatment, however, nonnative species had been reduced to a minor component of the understory, suggesting that the invasion risk is highly diminished. Furthermore, our results suggest that the plant community has not stabilized, as changes are likely still occurring 6 years after treatments. A long-term monitoring program is essential to assessing whether observed patterns are successional or persistent changes, as community change occurs slowly in semiarid climates of the Southwest.

\section{ACKNOWLEDGMENTS}

Thanks to the Coconino National Forest, especially A. Farnsworth, B. Thornton, T. Randall-Parker, and G. Waldrip; the Rocky Mountain Research Station, especially Carl Edminster; and staff and students of the Ecological Restoration Institute. This work was supported by the USDA Forest Service, \#05CR-11031600-079, and by the State of Arizona and Northern Arizona University. Support for the original establishment of the experiment was provided by the USDA Forest Service Rocky Mountain Research Station, Research Joint Venture Agreement No. RMRS-98134RJVA. 


\section{Literature Cited}

Abella, S., and W.W. Covington. 2004. Monitoring an Arizona ponderosa pine restoration: sampling efficiency and multivariate analysis of understory vegetation. Restoration Ecology 12:359-367.

Allen, C.D., M. Savage, D.A. Falk, K.F. Suckling, T.W. Swetnam, T. Schulke, P.B. Stacey, P. Morgan, M. Hoffman, and J.T. Klingel. 2002. Ecological restoration of southwestern ponderosa pine ecosystems: a broad perspective. Ecological Applications 12:1418-1433

ANDERSON, M.J. 2001. A new method for non-parametric multivariate analysis of variance. Austral Ecology 26:32-46.

BAKKer, J.D., AND M.M. MoORE. 2007. Controls on vegetation structure in southwestern ponderosa pine forests, 1941-2004. Ecology 88:2305-2319.

Clarke, K.R. 1993. Non-parametric multivariate analysis of changes in community structure. Australian Journal of Ecology 18:117-143.

Covington, W.W., P.Z. Fulé, M.M. Moore, S.C. Hart, T.E. Kolb, J.N. Mast, S.S SACKett, and M.R. WAGNER. 1997. Restoring ecosystem health in ponderosa pine forests of the Southwest. Journal of Forestry 95:23-29.

Covington, W.W., And M.M. Moore. 1994. Southwestern ponderosa forest structure: changes since EuroAmerican settlement. Journal of Forestry 92:39-47.

Crawford, J., C. Wahren, S. Kyle, and W. Moir. 2001. Responses of exotic plant species to fires in Pinus ponderosa forests in northern Arizona. Journal of Vegetation Science 12:261-268.

Dodge, R.S., P.Z. Fulé, AND C. Hull Sieg. 2008. Dalmatian toadflax (Linaria dalmatica) response to wildfire in a southwestern USA forest. Ecoscience 15:213-222.

DufrênE, M., AND P. LEGENDRE. 1997. Species assemblages and indicator species: the need for a flexible asymmetrical approach. Ecological Monographs 67:345-366.

Faith, D.P., P.R. Minchin, And L. BELbin. 1987. Compositional dissimilarity as a robust measure of ecological distance. Vegetatio 69:57-68.

Fornwalt, P.J., M.R. Kaufmann, and T.J. Stohlgren. 2010. Impacts of mixed severity wildfire on exotic plants in a Colorado ponderosa pine-Douglas-fir forest. Biological Invasions 12:2683-2695.

Fulé, P.Z., W.W. Covington, and M.M. Moore. 1997. Determining reference conditions for ecosystem management of southwestern ponderosa pine forests. Ecological Applications 7:895-908.

Fulé, P.Z., D.C. Laughlin, and W.W. Covington. 2005. Pine-oak forest dynamics five years after ecological restoration treatments, Arizona, USA. Forest Ecology and Management 218:129-145.

Fulé, P.Z., C. McHugh, T.A. Heinlein, and W.W. CovINGTON. 2001. Potential fire behavior is reduced following forest restoration treatments. Pages 28-35 in RMRS-P-22. USDA Forest Service, Rocky Mountain Research Station, Fort Collins, CO.

Griffis, K.L., J.A. Crawford, M.R. Wagner, and W.H. MOIR. 2001. Understory response to management treatments in northern Arizona ponderosa pine forests. Forest Ecology and Management 146:239-245.

HobBs, R.J., And D.A. NorTon. 1996. Towards a conceptual framework for restoration ecology. Restoration Ecology 4:93-110.
Huisinga, K.D., D.C. Laughlin, P.Z. Fulé, J.D. Springer, AND C.M. MCGLONE. 2005. Effects of an intense prescribed fire on understory vegetation in a mixed conifer forest. Journal of the Torrey Botanical Society 132:590-601.

Korb, J.E., P.Z. Fulé, And B. Gideon. 2007. Different restoration thinning treatments affect level of soil disturbance in ponderosa pine forests of northern Arizona, USA. Ecological Restoration 25:43-49.

Korb, J.E., N.C. Johnson, And W.W. Covington. 2004. Slash pile burning effects on soil biotic and chemical properties and plant establishment: recommendations for amelioration. Restoration Ecology 12:52-62.

KuenZI, A.M., P.Z. FulÉ, AND C.H. SIEG. 2008. Effects of fire severity and pre-fire stand treatment on plant community recovery after a large wildfire. Forest Ecology and Management 255:855-865.

Laughlin, D.C., And P.Z. Fulé. 2008. Wildland fire effects on understory plant communities in two fireprone forests. Canadian Journal of Forest Research 38:133-142.

Laughlin, D.C., M.M. Moore, J.D. Bakker, C.A. Casey, J.D. SPRINGER, AND P.Z. FulÉ. 2006. Assessing targets for the restoration of herbaceous vegetation in ponderosa pine forests. Restoration Ecology 14:548-560.

Laughlin, D.C., M.M. Moore, and P.Z. Fulé. 2011. A century of increasing pine density and associated shifts in understory plant strategies. Ecology 92: $556-561$.

Mast, J.N., P.Z. Fulé, M.M. Moore, W.W. Covington, AND A.E.M. WALTz. 1999. Restoration of presettlement age structure of an Arizona pine forest. Ecological Applications 9:228-239.

McCune, B., AND J.B. Grace. 2002. Analysis of ecological communities. MjM Software Design, Gleneden Beach, OR.

McCune, B., And M.J. MefFord. 2006. PCORD. Multivariate analysis of ecological data. Version 5.10. MjM Software, Gleneden Beach, OR.

McGlone, C.M., J.D. Springer, and W.W. Covington. 2009a. Cheatgrass encroachment on a ponderosa pine ecological restoration project in northern Arizona. Ecological Restoration 27:37-46.

McGlone, C.M., J.D. Springer, and D.C. Laughlin. $2009 \mathrm{~b}$. Can pine forest restoration promote a diverse and abundant understory and simultaneously resist nonnative invasion? Forest Ecology and Management 258:2638-2646.

MetLen, K.L., AND C.E. FiedLer. 2006. Restoration treatment effects on the understory of ponderosa pine/ Douglas-fir forests in western Montana, USA. Forest Ecology and Management 222:355-369.

Miller, G., N. Ambos, P. Boness, D. Reyher, G. Robertson, K. Scalzone, R. Steinke, and T. Subirge. 1995. Terrestrial ecosystem survey of the Coconino National Forest. USDA Forest Service Southwestern Region, Albuquerque, NM.

Moore, M.M., C.A. Casey, J.D. Bakker, J.D. Springer, P.Z. Fulé, W.W. Covington, and D.C. Laughlin. 2006. Herbaceous vegetation responses (19922004 ) to restoration treatments in a ponderosa pine forest. Rangeland Ecology and Management 59: 135-144.

Moore, M.M., W.W. Covington, And P.Z. Fulé. 1999. Reference conditions and ecological restoration: a southwestern ponderosa pine perspective. Ecological Applications 9:1266-1277. 
Moore, M.M., AND D.A. Deiter. 1992. Stand density index as a predictor of forage production in northern Arizona pine forest. Journal of Range Management 45:267-271.

Moore, M.M., D.W. Huffman, P.Z. Fulé, W.W. CovingTON, AND J.E. CROUSE. 2004. Comparison of historical and contemporary forest structure and composition on permanent plots in southwestern ponderosa pine forest. Forest Science 50:162-176.

[NOAA] National Oceanic and Atmospheric AdminisTRATION. 2005. Available from: http://www.noaa.gov

Roccaforte, J.P., P.Z. Fulé, And W.W. Covington. 2010. Monitoring landscape-scale ponderosa pine restoration treatment implementation and effectiveness. Restoration Ecology 18:820-833.

SABO, K.E., C.H. Sieg, S.C. HaRT, AND J.D. Bailey. 2009 The role of disturbance severity and canopy closure on standing crop of understory plant species in ponderosa pine stands in northern Arizona, USA. Forest Ecology and Management 257:1656-1662.

SAS Institute, InC. 2004. JMP Version 8.0. SAS Institute, Inc., Cary, NC.
[SER] Society For Ecological Restoration. 2004. The SER primer on ecological restoration. Available from: http://www.ser.org.

Uresk, D.W., and K.E. Severson. 1989. Understoryoverstory relationships in ponderosa pine forests, Black Hills, South Dakota. Journal of Range Management 42:203-208.

USDA NRCS. 2009. The PLANTS Database [online] National Plant Data Center, Baton Rouge, LA. Available from: http://plants.usda.gov

USDI NPS. 2003. Western Region Fire Monitoring Handbook. USDI National Park Service, Western Regional Office, San Francisco, CA.

Wienk, C.L., C.H. Sieg, and G.R. McPherson. 2004 Evaluating the role of cutting treatments, fire and soil seed banks in an experimental framework in ponderosa pine forests of the Black Hills, South Dakota. Forest Ecology and Management 192:375-393.

Received 29 July 2010 Accepted 22 February 2011 